\title{
A NOCTURNAL BLOOMER
}

\section{by Keith F. Best, Research Station, Swift Current}

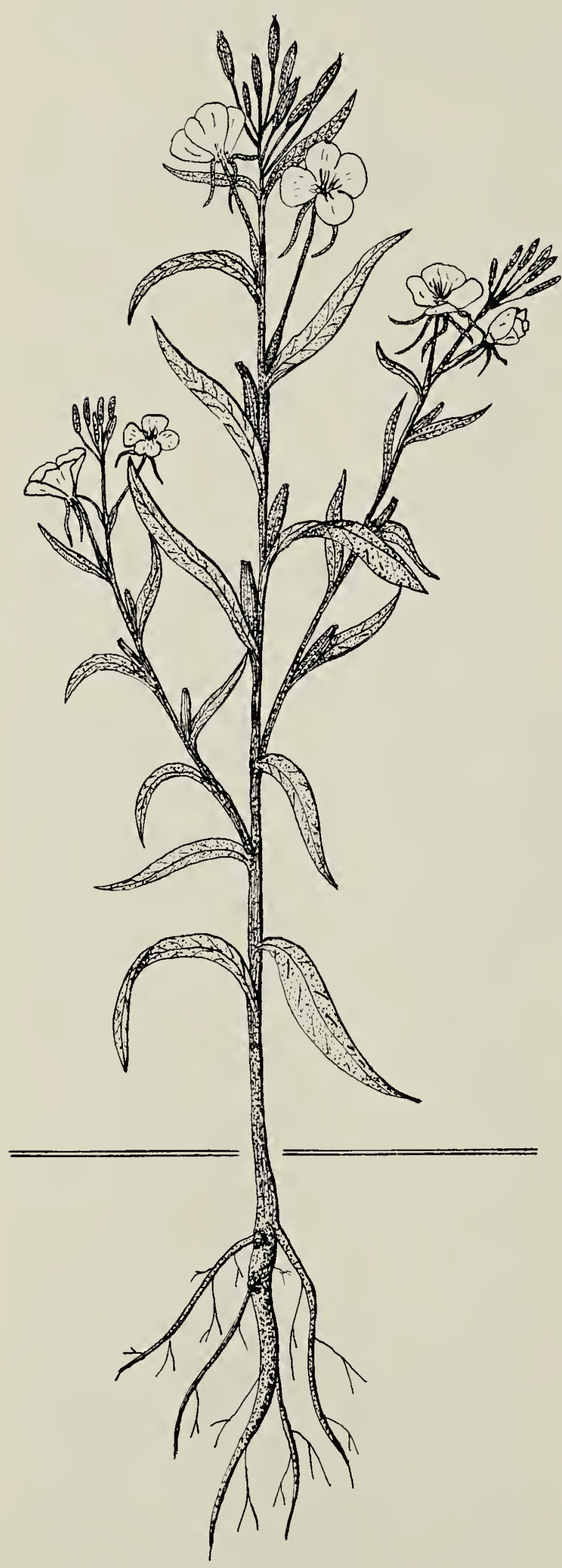

Western yellow evening-primrose Drawing by K. F. Best
The western yellow evening-primrose (Oenothera biennis var. canescens) is a native biennial. During the first year this plant forms a large flat mat or rosette of leaves and a fleshy tap root. In the second year of its growth, an erect leafy stem is produced often up to five feet in height.

Generally flowering in early July, the large yellow flowers are lemonscented with eight prominent and spreading stamens, the golden pollen loosely connected by cobwebby threads. A most drab and faded appearing plant during the daylight hours, it undergoes an amazing change as twilight approaches. The buds, in their upright position on the stem, begin to expand, the calyx suddenly bursts open and the four sepals bend sharply downward. One by one, the petals slowly unfold to expose the finished bloom and perfume the evening air. Opening just before sundown, they fade in the strong sunlight of the following day.

The fruit is a cylindrical capsule, somewhat hairy and opening from the top into four many-seeded cells. The seeds are very irregular in shape, dark reddish-brown, granular, ridged and often with winged margins.

A very common plant on lighter soils throughout the southwestern portion of the prairies, it is found in roadsides, pasturelands and waste places.

\section{BACK COPIES OF BLUE JAY WANTED}

To make a complete set of back copies of the Blue Jay for reference library use in Regina we find that we are short four numbers: Vol. 9, No. 3; Vol. 10, No. 4 and Vol. 15, No. 1 and 2. If you can help us please let us know. Other back copies are needed to complete other sets. Please write to Mrs. Hugh Smith, SNHS, Box 1121, Regina. 